\title{
Polymorphism of Selected Genes Coding for Xenobiotic-Metabolizing Enzymes and Susceptibility to Colorectal Cancer in a Saudi Population
}

\author{
Mansour A. Alghamdi \\ Department of Environmental Sciences, Faculty of Meteorology, Environment and Arid Land \\ Agriculture, King Abdulaziz University, KSA
}

\begin{abstract}
Colorectal cancer (CRC) is a threatening health problem in Saudi Arabia. Polymorphism of genes coding for xenobiotic-metabolizing enzymes (XME) represent significant risk for a variety of cancers related to the interaction of environmental and genetic factors. The present study aimed to investigate the contribution of CYP1A1 and NAT2 genes polymorphism in CRC. We conducted a hospital-based case-control study in Saudi population. Samples from buccal swabs were obtained from 116 de novo diagnosed cases of CRC and 72 controls. Seven polymorphisms in the two genes analysed: CYP1A1 T3801C, CYP1A1 C2453A, CYP1A1 A2455G, NAT2 G590A, NAT2 C481T, NAT2 G857A, and NAT2 A803G were identified. Among selected genes, CYP1A1 A2455G and NAT2 A803G genotypes demonstrated significant differences $(\mathrm{p}<0.05,0.001)$ and greater risk for developing CRC comparing to the wild genotype (OR: 7.65, 12.13 and 8.18 for GA, AA and GA+AA respectively for CYP1A1 A2455G; and 3.65, 4.24 and 4.17 for GA, GG and GA+GG respectively for NAT2 A803G). Remaining loci demonstrated no significance with risk. Of the seven polymorphisms screened, CYP1A1 A2455G and NAT2 A803G may be of importance to the colon carcinogenesis. Further large-scale studies are needed.
\end{abstract}

Keywords: genes, polymorphism, colorectal cancer.

\section{Introduction}

Colorectal cancer (CRC) is a major cause of mortality and morbidity worldwide. In Saudi Arabia, the incidence of CRC is increasing. According to the latest report of the National Cancer Registry (Al-Eid et al., 2011), CRC is the first most common cancer among Saudi males $(12.9 \%)$ and the third among the Saudi females $(9.4 \%)$, being the second most common malignancy among Saudis for all ages $(10.3 \%)$. Sporadic CRC is a typical multifactorial disease, arising from environmental exposures (air pollution, dietary carcinogens, cigarette smoke), susceptibility genes and the interaction between genotypes and environments (Khabaz, 2012 and Hezova et al., 2012)). Exposure to polycyclic aromatic hydrocarbons (PAHs) and heterocyclic amines (HCAs) have long been suspected to play a prominent role in CRC aetiology (Al-Saleh et al., 2008).

Genes coding for xenobiotic-metabolizing enzymes (XME) act as low-penetrance genes, and their functional polymorphisms confer significant risks for a variety of cancers related to the interaction of environmental and genetic factors (Agundez, 2004 and Ladero et al, 2012). Two important groups participate in the conversion of xenobiotics to more water soluble metabolites: the cytochrome P450 family and the N-acetyltransferases.

Among the members of Cytochromes P450 isozymes, CYP1A1, participates in the metabolism of a vast number of xenobiotics, and is important for the conversion of PAHs such as benzo[a]pyrene to mutagenic benzo[a]pyrene diol epoxide (BPDE) 
(Gelboin, 1980). In addition, CYP1A1 is one of the more significant P450 enzymes involved in the process of metabolic activation of many other environmental carcinogens (Androutsopoulos et al., 2009). The CYP1A1 T3801C variant involves a thymidine (T) to cytosine (C) substitution at position 3801 of the 3' non coding region downstream of the polyadenylation site (Androutsopoulos et al., 2009), and it has been associated with increased carcinogen activation ( Landi et al., 1994). The CYP1A1 A2455G leads to an Ile462 Val substitution in the heme-binding domain of exon 7 , with a concurrent increase in catalytic activity of the protein, while C2453A leads to a Thr461Asn substitution in the same domain as the previously mentioned polymorphism, with currently unknown consequences for the function of the encoded protein (Georgiadis et al., 2005).

The N-acetyltransferase 2 (NAT2), is expressed in the liver and the intestinal mucosa and catalyzes $\mathrm{N}$ - and $\mathrm{O}$-acetylation of certain pro-carcinogens, heterocyclic aromatic amines and aromatic amines. $\mathrm{N}$-acetylation takes place in the liver and results in Nhydroxi-metabolites which are excreted into the gastrointestinal lumen and are $\mathrm{O}$-acetylated at the level of the colorectal mucosa, forming covalent compounds that will bind to the DNA chain and will induce gene alterations and then formation of cancerous cells (Osian et al, 2010). Genetically determined differences in acetylation capacity may alter exposure to carcinogens and thus influence individual susceptibility to environmental exposures, suggesting that polymorphisms in NAT2 enzyme plays important role in colorectal carcinogenesis (Lilla et al., 2006). Individuals are divided in three principal phenotypes according to their genotype in fast acetylators, intermediated acetylators or slow acetylators. The NAT2 C481T, G857A, A803G and G590A genotypes are associated with slow acetylation (Woolhouse et al, 1997; Osian et $a l, 2010)$.

In this paper, we used the PCR-RFLP method to study the polymorphisms of the 2 genes coding for xenobiotic-metabolizing enzymes (CYP1A1and NAT2), and whether they represent a risk factor for colorectal cancer in Saudis.

\section{Study population}

Materials and Methods

De novo diagnosed cases of CRC treated in the King Abdulaziz University Hospital, Jeddah, Saudi Arabia were enrolled in this study. Samples from buccal swabs were obtained from 116 unrelated consecutive patients (60 males and 56 females) with colorectal cancer and 72 healthy individuals. They were included in the study after giving informed written consent. The colorectal cancer diagnosis was based on the histopahology of the patient. Control samples were obtained from healthy blood donors visiting the Blood Bank of the same hospital. The study proposal was scrutinized and approved by King Abdulaziz University Research Ethics Committee (protocol number 758-12, approval date 14/3/2012).

\section{Genotyping}

Genomic DNA was extracted from buccal swabs using DNA Blood Mini kit (Qiagen), following the manufacturer's protocol. The presence or absence of the polymorphisms was determined by PCR-RFLP analyses, using different enzymes according to the SNP to detect. PCR reactions were performed in $25 \mu \mathrm{l}$ containing $6 \mu \mathrm{g}$ of genomic DNA, $0,8 \mathrm{mM}$ each primer, $200 \mu \mathrm{M}$ of each dNTPs, 1,5 mM $\mathrm{MgCl}_{2}$ and $1 \mathrm{U}$ Promega GoTaq DNA Polymerase. After denaturation for $3 \mathrm{~min}$ at $93^{\circ} \mathrm{C}$, each PCR was performed for 35 cycles of $1 \mathrm{~min}$ at $93^{\circ} \mathrm{C}, 1 \mathrm{~min}$ at $59^{\circ} \mathrm{C}$ and $1 \mathrm{~min}$ at $72^{\circ} \mathrm{C}$. Final elongation step was $10 \mathrm{~min}$ at $72^{\circ} \mathrm{C}$. We used the same PCR conditions to 
amplified all genes studied. Negative nontemplate controls were included in each PCR and as an internal control we used $\beta$ globin gene.

PCR products were directly analyzed on a $2 \%$ agarose gel, except PCR products NAT2 C481T and NAT2 G857A, which were analyzed on a $1 \%$ agarose gel due to PCR failure.

Once we checked the PCR products, they were incubated with specific restriction enzymes in order to determine the polymorphism of interest. CYP1A1 A2455G were incubated for one hour at $65^{\circ} \mathrm{C}$ with 0.25 ul of BsrDI, NAT2 G590A for 4 hours at $37^{\circ} \mathrm{C}$ with $0.25 \mathrm{ul}$ of Taq $\mathrm{I}$, and all the others products for 1 hour at $37^{\circ} \mathrm{C}$ with 0.25 of the corresponding enzymes. The same aliquot of DNA was used to analyse all SNPs, and the digestions were terminated by taking out of the bath the samples and putting them at $-20^{\circ} \mathrm{C}$. The digested products were revealed in $3 \%$ agarose gel except for NAT2 C481T that were revealed in $1,5 \%$ agarose gel.

Based on the RFLP technique, we were able to identify seven polymorphisms in the two genes analysed: CYP1A1 T3801C, CYP1A1 C2453A, CYP1A1 A2455G, NAT2 G590A, NAT2 C481T, NAT2 G857A, and NAT2 A803G. Primers and restriction enzymes used to detected polymorphisms in the genes are presented in table 1.

Table 1. Primers and restriction enzymes used to detected polymorphisms in the genes.

\begin{tabular}{|c|c|c|}
\hline $\begin{array}{c}\text { Polymorphi } \\
\text { sm }\end{array}$ & Primer Sequence & Enzyme \\
\hline CYP1A1 & GGCTGAGCAATCTGA & Msp I \\
T3801C & CCCTA & \\
& $\begin{array}{c}\text { TAGGAGTCTTGTCTCA } \\
\text { TGCCT }\end{array}$ & \\
\hline CYP1A1 & CTGTCTCCCTCTGGTT & BsrD I \\
A2455G & ACAGGAAGC & \\
\hline
\end{tabular}

\begin{tabular}{|c|c|c|}
\hline CYP1A1 & TTCCACCCGTTGCAGC & Bsa I \\
C2453A & AGGATAGCC & \\
\hline NAT2 & CCTGGACCAAATCAG & Taq I \\
G590A & GAGAG & \\
\cline { 1 - 1 } NAT2 & ACACAAGGGTTTATTT & Dde I \\
A803G & TGTTCC & \\
\hline NAT2 & GTCACACGAGGAAAT & Kpn I \\
C481T & CAAATGC & \\
\hline NAT2 & GTTTCTAGCATGAAT & BamH I \\
G857A & CACTCTGC & \\
\hline
\end{tabular}

\section{CYP1A1 T3801C}

Amplification was done by incubation with Msp I enzyme. This endonuclease has CCGG as recognition sequence, and since in this case the wild type genotype is TT, it would only cut with at least one $\mathrm{C}$ allele. Hence, in the TT samples, we observed one fragment of $880 \mathrm{bp}$, while in the TC and CC genotype, there were three $(880 \mathrm{bp}, 692 \mathrm{bp}$ and $190 \mathrm{bp}$ ) and two bands ( $692 \mathrm{bp}$ and 190 bp) respectively.

\section{CYP1A1 C2453A}

We incubated the patients and control samples with Bsa I, an enzyme that has GGTCTC sequence as recognition site. In this case, the wild type genotype is $\mathrm{CC}$ and its presence is known by the apearence of two bands of $156 \mathrm{bp}$ and $50 \mathrm{bp}$. In the CA genotype, we observed 3 fragments of 204 bp, $156 \mathrm{bp}$ and $50 \mathrm{bp}$; and for the homozygous AA, the Bsa I could not cut so there was only the $204 \mathrm{bp}$ band.

\section{CYP1A1 A2455G}

To determine the CYP1A1 A2455G polymorphisms, the PCR products were incubated with the BsrD I endonuclease, that recognizes the GCAATG sequence. In the wild type genotype AA, this enzyme would cut the amplicon giving place to two fragments of $149 \mathrm{bp}$ and $55 \mathrm{bp}$. If the sample was heterozygous AG, three bands of 204 
bp, $149 \mathrm{bp}$ and $55 \mathrm{bp}$ will be observed. Lastly, the enzyme couldn't cut the homozygous genotype GG, and therefore in these cases there was only the 204 fragment.

\section{NAT2 G590A}

Samples were incubated with Taq I, which TCGA is the recognition sequence. Since the amplicon analyzed in this case, had more than one site of recognition for this endonuclease, the pattern of bands observed was more sophisticated than in the others analyses. We therefore concentrated on specific fragments in order to identify the polymorphism of interest. If the genotype was wild type $(\mathrm{GG})$, the pattern consisted of three bands: $170 \mathrm{bp}, 141 \mathrm{bp}$ and $109 \mathrm{bp}$. In the GA genotype, four bands of $283 \mathrm{bp}, 174$ bp, $142 \mathrm{bp}$ and $109 \mathrm{bp}$ were found. Finally, for the homozygous AA, two fragments of $283 \mathrm{bp}$ and $142 \mathrm{bp}$ were observed.

\section{NAT2 C481T}

The Kpn I endonuclease was used to analyse this polymorphism. This enzyme recognises the GGTACC sequence. The wild type genotype $\mathrm{CC}$ was identified with the observation of two fragments of $661 \mathrm{bp}$ and $550 \mathrm{bp}$. In the heterozygous CT genotype there were 3 bands of 1211 bp 661 $\mathrm{bp}$ and $550 \mathrm{bp}$ and for the TT samples only the $1211 \mathrm{bp}$ fragment was observed.

\section{NAT2 G857A}

The BamH I endonuclease, which has the GGATCC sequence as recognition site, was used to identify this polymorphism. The pattern of bands in the wild type genotype GG was two bands of $925 \mathrm{bp}$ and $286 \mathrm{bp}$, in the heterozygous GA three bands (1211 bp, $925 \mathrm{bp}$ and $286 \mathrm{bp}$ ) and in the AA genotype only one band of $1211 \mathrm{bp}$, because the BamH I could not cut neither allele.

\section{NAT2 A803G}

To determine the NAT2 A803G polymorphism, the samples were incubated with Dde I. This enzyme has the CTNAG recognition sequence and therefore, when the wild type genotype GG was present, three bands of $300 \mathrm{bp}, 99 \mathrm{bp}$ and $25 \mathrm{bp}$ were obtained. If the genotype was GA, fragments of $300 \mathrm{bp}, 297 \mathrm{bp}, 128 \mathrm{bp}, 99 \mathrm{bp}$, and $25 \mathrm{bp}$ were expected. However, 25 bp bands were not observed in the 3\% agarose gel; and the $300 \mathrm{bp}$ and the $297 \mathrm{bp}$ fragments, the difference being only $3 \mathrm{bp}$, were not differentiated. Finally, for the AA genotype there were only two bands: $297 \mathrm{bp}$ and 128 bp.

\section{Statistical analysis}

Statistical analyses were performed using the SNPStats statistical analysis software package (Sole, et al. 2006) and GraphPad Prism statistical software (GraphPad Software, San Diego, CA). SNPStats was used to estimate the halotype analysis and linkage disequilibrium in both investigated groups. Hardy-Weinberg equilibrium was tested for each polymorphism, calculating the chi-square test. All investigated polymorphisms were in Hardy-Weinberg equilibrium. The chi-square test, with one or two degrees of freedom (df), or Fisher's exact test was used to examine differences of genotype and allele frequencies between patients and controls. Odds ratios (OR) and $95 \%$ confidence interval (CI) were calculated. $\mathrm{P}$ values less than 0.05 were considered to be statistically significant.

\section{Results}

The personal characteristics of the individiuals included in the study are presented in Table 2. No significant difference in the age of participants between the different groups was detected. Concerning the tumor site, the number of cases with non sigmoid cancer was 
higher among male. Adenocarcinoma was the prevalent type among both sexes. Therefore, the results of the polymorphism among males and females were pooled both in cases and controls.

Table 2. Characteristics of the individuals included in the study.

\begin{tabular}{|c|c|c|c|c|}
\hline & \multicolumn{2}{|c|}{ Patients $(n=116)$} & \multicolumn{2}{|c|}{ Controls $(\mathrm{n}=72)$} \\
\hline & $\begin{array}{l}\text { Male } \\
(n=60)\end{array}$ & $\begin{array}{r}\text { Female } \\
(\mathrm{n}=56)\end{array}$ & $\begin{array}{l}\text { Male } \\
(n=37)\end{array}$ & $\begin{array}{l}\text { Female } \\
(\mathrm{n}=35)\end{array}$ \\
\hline Age years & $55.1 \pm 9.6$ & $52.5 \pm 12.9$ & $54.9 \pm 10.2$ & $56.9 \pm 11.7$ \\
\hline \multicolumn{5}{|l|}{ Tumor site } \\
\hline Non sigmoid & 24 & 17 & - & - \\
\hline Sigmoid & 19 & 18 & - & - \\
\hline Rectum & 17 & 21 & - & - \\
\hline \multicolumn{5}{|l|}{ Histopathology } \\
\hline Adenocarcinoma & 56 & 54 & - & - \\
\hline $\begin{array}{l}\text { Mucin } \\
\text { adenocarcinoma }\end{array}$ & 3 & 2 & - & - \\
\hline $\begin{array}{l}\text { Undifferentiated } \\
\text { small cell } \\
\text { carcinoma }\end{array}$ & 1 & 0 & - & - \\
\hline
\end{tabular}

Table 3 provides detailed information on the frequency of the multiple genotypes analysed. One hundred sixteen CRC samples were included in this study and were analysed for 7 SNPs in 2 genes. Association between polymorphism and the risk to develop colon cancer was assessed by comparing cases with the control group consisting of 72 individuals.

Table 3. Distribution of polymorphism in colorectal cancer patients and healthy population $(n=188)$.

\begin{tabular}{|l|l|l|l|l|l|}
\hline Polymorphism & Genotype & $\begin{array}{l}\text { Patients } \\
(\mathrm{n}=116)\end{array}$ & $\begin{array}{l}\text { Control } \\
(\mathrm{n}=72)\end{array}$ & OR (95\% CI) & P \\
\hline CYP1A1 & TT & $42(70 \%)$ & $34(65.4 \%)$ & 1 & \\
T3801C & TC & $14(23.3 \%)$ & $16(30.8 \%)$ & $0.74(0.60-3.3)$ & 0.58 \\
& CC & $4(6.7 \%)$ & $2(3.8 \%)$ & $1.74(0.11-3.5)$ & 0.46 \\
& TC+CC & $18(30 \%)$ & $18(34.6 \%)$ & $0.85(0.56-2.7)$ & 0.60 \\
\hline CYP1A1 & CC & $32(28.1 \%)$ & $22(30.6 \%)$ & 1 & \\
C2453A & CA & $76(66.7 \%)$ & $50(69.4 \%)$ & $0.96(0.50-1.83)$ & 0.59 \\
& AA & $6(5.3 \%)$ & $0(0 \%)$ & $0.00(0.00-\mathrm{NA})$ & 0.56 \\
\hline
\end{tabular}

\begin{tabular}{|l|l|c|c|l|l|}
\hline & CA+AA & $82(71.9 \%)$ & $50(69.4 \%)$ & $0.89(0.46-1.69)$ & 0.72 \\
& & & & & \\
\hline CYP1A1 & GG & $19(16.4 \%)$ & $46(63.9 \%)$ & 1 & \\
A2455G & GA & $82(70.7 \%)$ & $24(33.3 \%)$ & $7.65(2.66-19.25)$ & 0.000 \\
& AA & $15(12.9 \%)$ & $2(2.8 \%)$ & $12.13(2.68-$ & 0.000 \\
& GA+AA & $97(83.6 \%)$ & $26(36.1 \%)$ & $44.46)$ & 0.000 \\
& & & & $8.18(3.00-20.11)$ & \\
\hline NAT2 G590A & AA & $8(12.5 \%)$ & $12(17.1 \%)$ & 1 & 0.63 \\
& GA & $52(81.2 \%)$ & $52(74.3 \%)$ & $0.67(0.25-1.7)$ & 0.63 \\
& GG & $4(6.2 \%)$ & $6(8.6 \%)$ & $1.00(0.21-4.7)$ & 0.59 \\
& GA+GG & $56(87.5 \%)$ & $58(82.9 \%)$ & $0.69(0.26-1.8)$ & 0.45 \\
\hline NAT2 C481T & CC & $38(35.9 \%)$ & $34(54.8 \%)$ & 1 & \\
& CT & $46(43.4 \%)$ & $18(29 \%)$ & $1.44(0.21-0.89)$ & 0.064 \\
& TT & $22(20.8 \%)$ & $10(16.1 \%)$ & $1.21(0.21-1.22)$ & 0.059 \\
& CT+TT & $68(64.2 \%)$ & $28(45.2 \%)$ & $1.46(0.24-0.87)$ & 0.055 \\
\hline NAT2 G857A & GG & $42(36.2 \%)$ & $28(38.8 \%)$ & 1 & \\
& GA & $46(39.7 \%)$ & $31(43.1 \%)$ & $0.63(0.28-1.6)$ & 0.094 \\
& AA & $28(24.1 \%)$ & $13(18.1 \%)$ & $1.54(0.26-1.32)$ & 0.076 \\
& GA+AA & $74(63.8 \%)$ & $44(61.2 \%)$ & $0.57(0.25-1.12)$ & 0.099 \\
\hline NAT2 A803G & AA & $86(74.1 \%)$ & $66(91.7 \%)$ & 1 & \\
& GA & $26(22.4 \%)$ & $5(6.9 \%)$ & $3.65(1.39-9.57)$ & 0.006 \\
& GG & $4(3.4 \%)$ & $1(1.4 \%)$ & $4.24(2.45-16.91)$ & 0.000 \\
& GA+GG & $30(25.8 \%)$ & $6(8.3 \%)$ & $4.17(1.6-10.81)$ & 0.002 \\
\hline
\end{tabular}

\section{Discussion}

The incidence of CRC in the Kingdom of Saudi Arabia has been on a constant rise over the past few years with a prediction of increase in the coming years (Ibrahim et al, 2008; Mosly and Al Ahwal, 2012). This increase was reported to be over a three-fold incidence rise in males from 3.2\% (Al-Eid and Arteh, 2004) to $11.2 \%$ (Haya and Al-Eid, 2007) within around 7 years. A parallel trend in females was observed from $2.7 \%$ to $8.8 \%$ for the same period. The increasing incidence was referred to demographic changes and the implementation of Western lifestyle (WCRF, 2014).

Little of the genetic variation in CRC has been explained and it is likely that many more variants remain to be identified (Figueiredo et al, 2011). In Saudi Arabia, few are the studies dealing with gene polymorphism and the susceptibility to CRC. No association could be detected between the susceptibility to CRC and resistin promoter C-180G genotype (AlHarithy and Al-Ghafari, 2010), PARP-1 Val762Ala (Alshammari et al, 2014), GSTP1 Ile105Val (Khabaz, 2012) and autozygosity (Siraj et al, 2012). On the other hand, MMP- 
2C-qa306T ANP (Saeed et al, 2013 a), PARP1 Lys933Asn and Parp-1 Lys945Asn (Alshammari et al, 2014), rs 961253 Lys25Arg (Khan et al, 2014), CYP1A1, CYP2E1 and GSTM1 (Saeed et al, 2013b) were significantly associated withCRC.

A mass evidence shows susceptibility to cancer is mediated by alterations in detoxifying capacity of genetically determined factors that play a role in cellular defence mechanism against endogenous and exogenous substances, many of which have carcinogenic potential (Khabaz, 2012).

Activation of procarcinogens is mediated mainly by cytochrome P-450 enzymes, phase I biometabolism of xenobiotics, (Koutros et al, 2014). Among phase I enzymes, the CYP1A1 gene was studied in the present work. Only one of the three studied SNPs, the CYP1A1 $\mathrm{A} 2455 \mathrm{G}$ variant (minor allele), emerged as a risk allele in colorectal cancer patients. Polymorphisms of CYP1A1 A2455G involves the $A>G$ transition in codon 462 (exon 7) leading to the substitution of isoleucine to valine (Ile462Val). As a result, the enzyme is activated and higher amount of carcinogenic molecules are obtained, especially from polycyclic aromatic hydrocarbons. These may be involved in the carcinogenesis of intestinal mucosa (Akiyama et al, 2003). The contribution of CYP1A1 A2455G polymorphism to colorectal cancer risk was documented in many previous studies (Gil et al, 2012; Jin et al, 2011; Zheng et al 2012; Gil et al 2014).

On the other hand, the present study failed to detect any significant change when CYP1A1 T3801C was analysed. This is in agreement with studies in other populations, for example, no statistically significant differences in CYP1A1 T3801C genetic variations have been shown in Italy (Boccia et al, 2007), the United Kingdom (Ye and Parry, 2002) and in Lebanon
(Slattery et al, 2004). But other studies showed that CYP1A1 T3801C is significantly associated with CRC in Saudi population (Saeed et al, 2014b) and in Japanese living in Hawaii (Nisa et al, 2010). It is noteworthy to mention here that allelic frequency of CYP1A1 T3801C in Arabs was reported to be only comparable to that reported in Africans; and that the allelic frequency of CYP1A1 A2455G, while closer to Caucasians, is significantly different from all other populations ( $\mathrm{Bu}$ et al, 2004).

Elimination of environmental chemicals proceeds through the complex detoxification mechanisms and is associated with phase II biometabolic enzymes (Koutros et al, 2014). The impact of genetic variation in phase II xenobiotic clearance enzymes has been attributed among others to genes as NAT2 (Nacetyl transferase 2) which was analysed in the present study, and GSTT1 (glutathione Stransferase T1) (Sachse et al, 2002). The four studied SNPs of the NAT2 gene included in the present study are associated with slow acetylation (Osian et al, 2010). Slow acetylator status in Arabs was found to be similar to Caucasians and signficantlu higher than in Asians (Bu et al, 2004). Only the NAT2 A803G showed significant variations in CRC patients. An impaired detoxification of aromatic amines such as 4-aminobiphenyl, for which Nacetylation is an important detoxification pathway (Hein et al, 1993), may explain the findings of greater risk among NAT slow acetylators to develop CRC. This finding is in line with several previous studies (Tiemersma et al, 2004; Welfare et al, 1997Moslehi et al, 2005; Da Silva et al, 2011; Lilla et al, 2012, Nothlings et al, 2009; Andersen and Vogel 2015).

Although it is difficult to arrive at a definite conclusion from a small data set, our preliminary results support the hypothesis of the potential role of polymosphism of genes 
coding for XME in the colon carcinogenesis. Obviously, further studies with large-scale studies including other XME genes are needed to a better understanding of the role of genetic factors in CRC aetiology in Saudi population.

\section{Acknowlegement}

The author acknowledges Prof. Suhad Bahajri, Department of Clinical Biochemistry, Faculty of Medicine, King Abdulaziz University, Jeddah, Saudi Arabia, for her valuable assistance in sample collection.

\section{References}

Agundez, J. (2004) Cytochrome P450 gene polymorphism and cancer. Curr. Drug Metab. 5: 211-224.

Al-Eid, H. and Arteh, S. (2004) Cancer Incidence Report 1999-2000. National Cancer Registry.

Al-Eid, H.S., Bazarbashi, S. and Al Zahrani, A. (2011) Cancer Incidence Report, Saudi Arabia 2005. Saudi Cancer Registry website. Available at: http://www.scr.org.sa/reports/. Assessed on December 29, 2014.

Al-Harithy, R. and Al-Ghafari, A. (2010) Resistin in human colon cancer. Increased expression independently of resistin promoter C-180G genotype. Saudi Med J 31(5): 495-500.

Al-Saleh, I., Arif, J., El-Doush, I., Al-Sanea, N., Jabbar, A., Billedo, G., Shinwari, N., Mashhour, A. and Mohamed, G. (2008) Carcinogen DNA adducts and the risk of colon cancer: case-control study. Biomarkers 13(2): 201-216.

Alshammari, A., Shalaby, M., Alanazi, M. and Saeed, H. (2014) Novel mutations of the PARP-1 gene associated with colorectal cancer in the Saudi population. Asian Pac J Cancer Prev 15(8): 3667-3673.

Andersen, V. and Vogel, U. (2015) Interactions between meat intake and genetic variation in relation to colorectal cancer. Genes Nutr. 10(1): 448.

Androtsopoulos, V., Tsatsakis, A. and Spandidos, D. (2009) Cytochrome P450 CYP1A1: wider roles in cancer progression and prevention. BMC Cancer 9: 187.

Boccia, S., Sayed-Tabatabaei, F.A., Persiani, R. and et al. (2007) Polymorphisms in metabolic genes, their combination and interaction with tobacco smoke and alcohol consumption and risk of gastric cancer: a casecontrol study in an Italian population. BMC Cancer 7: 206.

Bu, R., Gutierrez, M., Al-Rasheed, M., Belgaumi, A. and Bhatia, K. (2004) Variable drug metabolism genes in Arab population. Pharmacogenomics J. 4: 260-266.
Da Silva, T., Felipe, A., De Lima, J., Oshima, C. and Forones, N. (2011) N-acetyltransferase 2 genetic polymorphisms and risk of colorectal cancer. World $J$ Gastroenterol. 17(6): 760-765.

Figueiredo, J., Lewinger, J.P., Song, C., Campbell, P., Conti, D., Edlund, C., Duggan, D., Rangrej, J., Lemire, M., Hudson, T., Zanke, B., Cotterchio, M., Gallinger, S., Jenkins, M., Hopper, J., Haile, R., Newcomb, P., Potter, J., Baron, J., Le Marchand, L. and Casey, G. (2011) Genotype-environment interactions in microsatellite stable/ microsatellite instability-low colorectal cancer: Results from a genome-wide association study. Cancer Epidemiol Biomarkers 20(5): 758-766.

Gelboin, H.V. (1980) Benzo[alpha]pyrene metabolism, activation and carcinogenesis: role and regulation of mixed-function oxidases and related enzymes. Physiol Rev. 60, (4): 1107-1166.

Georgiadis, P., Topinka, J., Vlachodimitropoulos, D., Stoikidou, M., Gioka, M., Stephanou, G., Autrup, H., Demopoulos, N., Katsouyanni, K., Sram, R. and Kyrtopoulos, S. (2005) Interactions between CYP1A1 polymorphisms and exposure to environmental tobacco smoke in the modulation of lymphocyte bulky DNA adducts and chromosomal aberrations. Carcinogenesis 26(1): 93-101.

Gil, J., Gaj, P., Misiak, P., Ostrowski, J., Karpinski, P., Jarczynska, A., Kielan, W. and Sasiadek, M . (2014) CYP1A1 Ile462Val polymorphism and colorectal cancer risk in Polish patients. Med Oncol. 31: 72.

Gil, J., Ramsey, D., Stembalska, A., Karpinski, P., Pesz, K.A., Laczmanska, I., Leszczynski, P., Grzebieniak, Z. and Sasiadek, M.M. (2012) The C/A polymorphism in intron 11 of the XPC gene plays a crucial role in the modulation of an individual's susceptibility to sporadic colorectal cancer. Mol Biol Rep. 39(1):527-34.

Haya, S. and Al-Eid, H. (2007) Cancer Incidence and Survival Report. Saudi Cancer Registry.

Hein, D.W., Doll, M.A., Rustan, T.D. and et al. (1993) Metabolic activation and deactivation of arylamine carcinogens by recombinant human NAT1 and polymorphic NAT2 acetyltransferases. Carcinogenesis 14:1633-8

Hezova, R., Bienertova-Vasku, J., Sachlova, M., Brezkova, V., Vasku, A., Svoboda, M., Radova, L., Kiss, I., Vyzula, R. and Slaby, O. (2012) Common polymorphisms in GSTM1, GSTT1, GSTP1, GSTA1 and susceptibility to colorectal cancer in the Central European population. European J of Med. Res. 17:17.

Ibrahim, E., Zeeneldin, A., El-Khodary, T. and et al. (2008) Past, present and future of colorectal cancer in the Kingdom of Saudi Arabia. Saudi J Gastroenterol 14: 178182.

Jin, J.Q., Hu, Y.Y., Niu, Y.M., Yang, G.L., Wu, Y.Y., Leng, W.D. and Xia, L.Y. (2011) CYP1A1 Ile462Val 
polymorphism contributes to colorectal cancer risk: a meta-analysis. World J Gastroenterol. 17(2):260-6.

Khabaz, M. (2012) The GSTP1 Ile105Val polymorphism is not associated with susceptibility to colorectal cancer. Asain Pacific J Cancer Prev. 13: 2949-2953.

Khan, W., Abduljaleel, Z., Alanazi, M. and Elrobh, M. (2014) Evidence of colorectal cancer risk associated variant Lys25Ser in the proximity of human bone morphogenetic protein 2. Gene 522(1): 75-83.

Koutros, S., Andreotti, G., Berndt, S.I., Hughes, Barry. K., Lubin, J.H., Hoppin, J.A., Kamel, F., Sandler, D.P., Burdette, L.A., Yuenger, J., Yeager, M., Alavanja, M.C. and Freeman, L.E. (2011) Xenobiotic-metabolizing gene variants, pesticide use, and the risk of prostate cancer. Pharmacogenet Genomics. 21(10):615-23.

Ladero, J., Agundez, J., Matinez, C., Amo, G., Ayuso, P. and Garcia-Martin, E. (2012) Analysis of the functional polymorphism in the cytochrome P450 CYP2C8 gene rs11572080 with regard to colorectal cancer risk. Frontiers in Genetics 3:278.

Landi, M.T., Bertazzi, P.A., Shields, P.G., Clark, G., Lucier, G., Garte, S.J., Cosma, G. and Caporaso, N.E. (1994) Association between CYP1A1 genotype, mRNA expression and enzymatic activity in humans. Pharmacogenetics 4(5): 242-246.

Lilla, C., Verla-Tebit, E., Risch, A., Jager, B., Hoffmeister, M., Brenner, H. and Chang-Claude, J. (2006) Effect of NAT1 and NAT2 genetic polymorphisms on colorectal cancer risk associated with exposure to tobacco smoke and meat consumption. Cancer Epidemiol Biomarkers Prev. 15(1): 99-107.

Moslehi, R., Chen, J., Hein, D.W. and et al. (2005) Cigarette smoking, NAT1 and NAT2 susceptibility haplotypes, and the risk of advanced colorectal adenoma. Proc Am Assoc Cancer Res 46:769.

Mosli, M. and Al-Ahwal, M. (2012) Colorectal cancer in the Kingdom of Saudi Arabia: Need for screening. Asian Pac J Cancer Prev. 13: 3809-3813.

Nisa, H., Kono, S., Yin, G. and et al (2010) Cigarette smoking, genetic polymorphisms and colorectal cancer risk: the Fukuoka colorectal cancer study. BMC Cancer 10: 274.

Nothlings, U., Yamamoto, J., Wilkens, L., Murphy, S., Park, S., Henderson, B. and et al. (2009) Meat and heterocyclic amine intake, smoking, NAT1 and NAT2 polymorphisms, and colorectal cancer risk in the lultirthnic cohort study. Cancer Epidemiol Biomark Prev. 18(7): 2098-2106

Osian, G., Procopciuc, L., Vlad, L., Lancu, C., Criesta, P., Mocan, T. and Mocan, L. (2010) NAT2 polymorphisms and sporadic colorectal cancer survival. $J$ Gastrointestin Liver Dis. 19(4): 361-368.
Sachse, C., Smith, G., Wilkie, M.J., Barrett, J.H., Waxman, R., Sullivan, F., Forman, D., Bishop, D.T. and Wolf, C.R. Colorectal Cancer Study Group. (2002). A pharmacogenetic study to investigate the role of dietary carcinogens in the etiology of colorectal cancer. Carcinogenesis 23(11):1839-49.

Saeed, H., Alanazi, M., Nounou, H., Shalaby, M., Semlali, A., Azzam, N., Aljebreen, A., Alharby, O., Parine, N., Shaik, J. and Arafaha, M. (2013b) Cytochrome P450 1A1, 2E1 and GSTM1 gene polymorphisms and susceptibility to colorectal cancer in the Saudi population. Asian Pacific J Cancer Prev 14: 3761-3768.

Saeed, H., Alanazi, M., Parine, N., Shaik, J., Semlali, A., Alharbi, O., Azzam, N., Aljebreen, A., Almadi, M. and Shalaby, M. (2013a) Matrix metalloproteinase-2 (-1306 c) t) promoter polymorphism and risk of colorectal cancer in the Saudi population. Asian Pac J Cancer Prev 14(10): 6025-6030.

Siraj, A., Khalak, H., Sultana, M., Al-Rasheed, M., Bavi, P., Al-Sanea, N., Al-Dayel, F., Uddin, Sh., Alkuraya, F. and Al-Kuraya, K. (2012) Colorectal cancer risk is not associated with increased levels of homozygosity in Saudi Arabia. Genet Med 14(8): 720-728.

Slattery, M.L., Samowtiz, W., Ma, K. and et al. (2004) CYP1A1, cigarette smoking, and colon and rectal cancer. Am J Epidemiol. 160: 842-52.

Tiemersma, E.W., Bunschoten, A., Kok, F.J., Glatt, H., de Boer, S.Y. and Kampman, E. (2004). Effect of SULT1A1 and NAT2 genetic polymorphism on the association between cigarette smoking and colorectal adenomas. Int J Cancer 108:97-103.

WCRF， W.C.R.F. (2014， 1/22/2014). World Cancer Research Fund International. http://www.wcrf.org/ World Cancer Research Fund International. Accessed on January $5^{\text {th }}, 2015$.

Welfare, M.R., Cooper, J., Bassendine, M.F. and Daly, A.K. (1997) Relationship between acetylator status, smoking, and diet and colorectal cancer risk in the northeast of England. Carcinogenesis 18:1351-4.

Woolhouse, N.M., Qureshi, M.M., Bastaki, S.M., Patel, M., Abdulrazzaq, Y. and Bayoumi, R.A. (1997) Polymorphic $\mathrm{N}$-acetyltransferase (NAT2) genotyping of Emiratis, Pharmacogenetics, 7, (1): 73-82.

Ye, Z. and Parry, J.M. (2002) Genetic polymorphisms in the cytochrome P450 1A1, glutathione S- transferase M1 and $\mathrm{T} 1$, and susceptibility to colon cancer. Teratog Carcinog Mutagen. 22: 385-92.

Zheng, Y., Wang, J.J., Sun, L. and Li, H.L. (2012) Association between CYP1A1 polymorphism and colorectal cancer risk: a meta-analysis. Mol Biol Rep. 39(4):3533-40. 


\title{
تعدد الأشكال لبعض الجينات المختارة التي تشفر إنزيمات أيض الدخيل الحيوي و القابلية لسرطان القولون و المستقيم في مجتمع سعودي
}

\section{منصور أحمد الغامدي}

\author{
قسم العلوم البيئية، كلية الأرصاد والبيئة وزراعة المناطق الجافة، \\ جامعة الملك عبدالعزيز، جدة، المدلكة العربية السعودية
}

المستخلص. يعتبر سرطان القولون مشكلة صحية منذرة في المملكة العربية السعودية. ويمنل تعدد الأشكال في الجينات المشفرة لإنزيمات أيض الاخيل الحيوي خطر ا معنويا للعديد من أنواع السرطان المرتبطة بالتقاعل بيمن العو امل البيئية و الجينية. وتهدف الدراسة الحالية إلى بحث مشاركة تعدد الأشكال للجينات CYP1A1، و NAT2 في الإصابة بسرطان القولون و المستقيم. طرق البحث: تم القيام بدر اسة "عينة الحالة المر اقبة في مستشفى" لاى مجتمع سعودي. تم جمع عينات مسحية من الفم لمائة وستة عشر حالة سرطان القولون و المستقيم حديثة التشخيص، و اثنتين وسبعين فرد كعينة ضابطة. تم تحليل سبعة أثكال تعددية للجينات CYP1A1، و NAT2، وهي: CYP1A1 T3801C, CYP1A1 C2453AA CYP1A1 A2455G, NAT2 G590A, NAT2 C481T, NAT2 G857A, and NAT2 A803G الأثكال التعددية CYP1A1 A2455G، و NAT2 A803G كانت مختلفة معنويا (p<0.05, 0.001) وتمثل خطرًا أكبر في تكوين سرطان القولون و المستقيم عند المقارنة بالشكل التعددي البري (معامل الخطر:

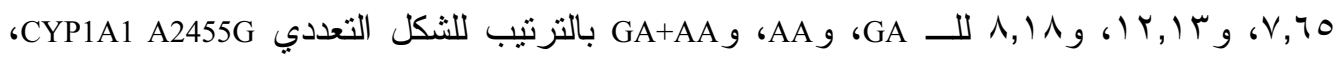

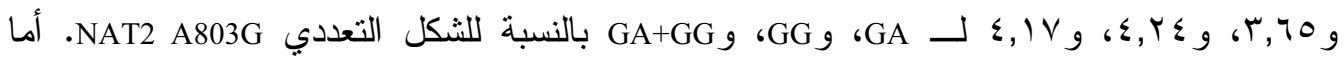
المو اقع الأخرى فلم تظهر أي خطر معنوي. و الخلاصة، أنه من الأشكال التعددية السبعة التي تم كثفها، قد تكون الأشكال التعددية CYP1A1 A2455G، و وNAT2 A803G أهمية في عملية سرطنة القولون. و هناك حاجة لمزيد من الدر اسات على نطاق أوسع. الكلمات الدالة: الجينات، و التعدد الثكلي، وسرطان القولون و المستقيم. 
